ARTICLE

Received 25 Jan 2013 | Accepted 8 Mar 2013 | Published 16 Apr 2013

\title{
Arginine clustering on calix[4]arene macrocycles for improved cell penetration and DNA delivery
}

\author{
Valentina Bagnacani ${ }^{1}$, Valentina Franceschi ${ }^{2}$, Michele Bassi ${ }^{1}$, Michela Lomazzi ${ }^{1}$, Gaetano Donofrio ${ }^{2}$, \\ Francesco Sansone ${ }^{1}$, Alessandro Casnati ${ }^{1} \&$ Rocco Ungaro ${ }^{1}$
}

Cell-penetrating peptides are widely used as molecular transporters for the internalization inside cells of various cargo, including proteins and nucleic acids. A special role is played by arginine-rich peptides and oligoarginines covalently linked or simply mixed with the cargo. Here we report cell-penetrating agents in which arginine units are clustered on a macrocyclic scaffold. Instead of using long peptides, four single arginine units were covalently attached to either the upper or lower rim of a calix[4]arene, kept in the cone conformation building a 'parallel' cyclic array. These new macrocyclic carriers show high efficiency in DNA delivery and transfection in a variety of cell lines.

\footnotetext{
${ }^{1}$ Dipartimento di Chimica, Università degli Studi di Parma, Parco Area delle Scienze 17/a, 43124 Parma, Italy. ${ }^{2}$ Dipartimento di Scienze Medico-Veterinarie Università degli Studi di Parma, Via del Taglio 6, 43126 Parma, Italy. Correspondence and requests for materials should be addressed to G.D.

(email: gaetano.donofrio@unipr.it) or to F.S. (email: francesco.sansone@unipr.it) or to A.C. (email: casnati@unipr.it).
} 
C ell-penetrating peptides (CPPs) $)^{1-3}$ are widely used as molecular transporters for the internalization of various molecular and macromolecular cargo inside cells. Among them, arginine-rich peptides, such as HIV-1 TAT fragments 3 ,4 and oligoarginines ${ }^{5}$, have a special role. They can be covalently linked to or, more simply, mixed with the cargo, both strategies showing examples of significant translocation activity ${ }^{6}$. Because of these features, arginine-rich peptides can also help the penetration of nucleic acids across the cell membranes opening interesting perspectives in gene delivery, which is a necessary prerequisite for gene therapy ${ }^{7-11}$. In this context, following a non-covalent approach ${ }^{12,13}$, CPPs are used in formulation, either simply with the nucleic acid filaments or in a ternary assembly, including also a cationic lipid. Alternatively, they can be covalently linked to a lipid structure (Fig. 1a) in which the resulting ratio between arginine units and lipophilic tails is, in general, of several to one $\mathrm{e}^{14-16}$. A certain degree of rigidity imposed to the peptide structure, for example by cyclization of the arginine-rich sequences, seems to further enhance the cellular uptake $^{17}$. We reasoned that the clustering of arginine units on a spatially well-defined macrocyclic scaffold (Fig. 1b) could be exploited to enhance their cell-penetrating properties, and we report here the first example of this strategy, applied to DNA delivery and cell transfection. Considering that cyclodextrins ${ }^{18}$ and calixarenes ${ }^{19-25}$ are non-toxic and have been used as scaffolds for building gene delivery systems, we selected calix[4] arene as the macrocyclic platform and anchored to it single arginine units rather than complex arginine-rich peptides, or linear and long oligoarginines, to limit to a ratio of one to one between amino acids and the lipophilic tails (Fig. 1b). Therefore, we herein describe the synthesis and the DNA binding and condensation properties of two new C-linked L-argininocalix[4]arenes and two acyclic Gemini-type analogues. Moreover, taking into account the several examples of polylysines used for cell transfection ${ }^{26}$, we also prepared a calixarene adorned at the upper rim with four L-lysine units, to verify the differences in activity related to the two types of amino acid. Gene-delivery studies with these compounds showed that the upper-rim arginine derivative 3a, in particular, has exceptional transfection properties and low cytotoxicity, suggesting that the proposed strategy of clustering arginine units on rigid, lipophilic macrocyclic scaffolds could be envisaged as a new approach to improve cell penetration of cargo.

\section{Results}

Synthesis. The upper rim tetraarginino- (3a) and tetralysinocalix[4] arene (3b), belonging to the class of C-linked peptidocalixarenes ${ }^{27,28}$, were prepared (Fig. 2) starting from tetramino-tetrahexyloxycalix[4] arene $\mathbf{1}$, selected on the basis of the previous experimental observation ${ }^{19}$, such that in the upper rim guanidinocalix[4]arene vectors the presence of hexyl chains at the lower rim allowed cell transfection in the absence of DOPE (1,2-dioleoyl-sn-glycero-3-phosphoethanolamine), with the same efficiency shown in the presence of this helper. The lower rim tetraargininocalix[4]arene $\mathbf{6}$ was synthesized from the tetrapropylamino precursor 4 (ref. 29; Fig. 2). In the synthetic pathway of both compounds $3 \mathbf{a}$ and 6 , by using $N_{\alpha}$-Boc- $N_{\omega}$-tosylL-arginine or $N_{\alpha}$-Fmoc- $N_{\omega}$-Mtr-L-arginine, the unexpected cleavage of the amide bonds between the amino acid units and the calixarene occurred during the deprotection steps. On the contrary, we did not observe this side reaction either when $N_{\alpha}$-Boc- $N_{\omega}$-Pbf-L-arginine (Boc-L-Arg(Pbf)-OH) and $N_{\alpha}$-Cbz-Larginine were attached at the upper and at the lower rim of $\mathbf{1}$ and 4 , respectively, or during the removal of Boc groups from the lysine functionalized compound $\mathbf{2 b}$.
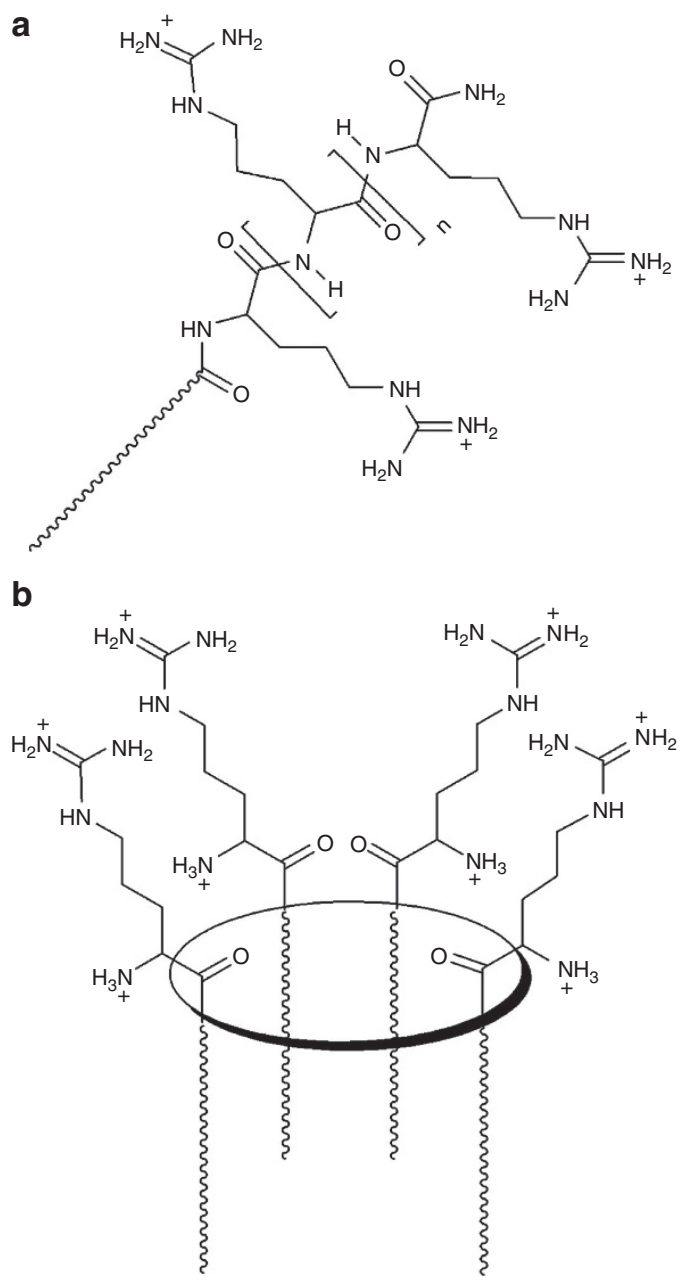

Figure 1 | Arginine arrays. (a) Linear versus (b) cyclic array. Ellipse represents a macrocyclic scaffold, wavy lines represent linear hydrocarbon chains.

The two Gemini-like derivatives (7 and 8 in Fig. 3) were prepared through similar procedures by successfully using Boc-L$\mathrm{Arg}(\mathrm{Pbf})-\mathrm{OH}$ for both (details in Supplementary Methods). After standard deprotection reactions, the chloride salts of peptidocalixarenes $\mathbf{3 a}, \mathbf{b}$ and $\mathbf{6}$, and of non-macrocyclic compounds 7 and $\mathbf{8}$ were isolated.

All compounds resulted to be water soluble, but although $\mathbf{3 a}$ largely tends to form aggregates (Supplementary Fig. S1) due to the presence of aliphatic chains at the lower rim, 6 showed sharp ${ }^{1} \mathrm{H}$ NMR signals in $\mathrm{D}_{2} \mathrm{O}$ (Supplementary Fig. S2), ruling out selfassembly phenomena even in the presence of the high concentrations of the inorganic salts $\left(\mathrm{NaCl}\right.$ and $\left.\mathrm{MgCl}_{2}\right)$ added to the sample to increase the ionic strength and to reproduce more closely the conditions of the Atomic Force Microscopy (AFM) and transfection experiments. In the latter conditions, $\mathbf{3 b}$, which is monomeric in pure $\mathrm{D}_{2} \mathrm{O}$, self-assembles in species in slow exchange equilibrium on the NMR time scale with the monomer, whose signals progressively disappear by increasing the salt concentration (Supplementary Fig. S3). This self-assembly activity, although not sufficient, seems an important prerequisite to induce DNA compactation and delivery.

DNA binding and condensation. Displacement of ethidium bromide (Supplementary Fig. S4) and electrophoresis mobility 

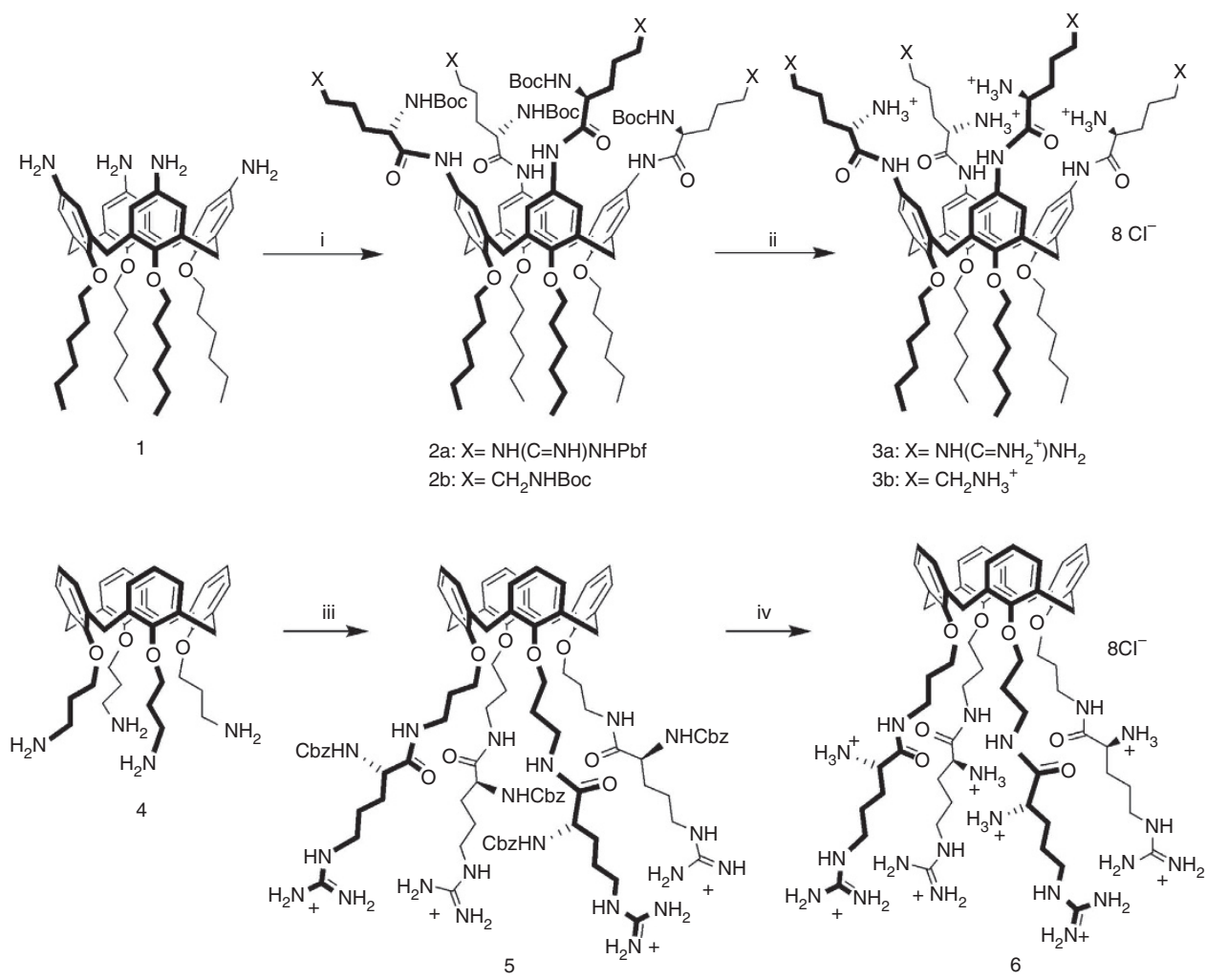

Figure 2 | Synthesis of peptidocalix[4]arenes 3a,b and 6. Reagents and conditions: (i) Boc-L-Arg(Pbf)-OH ( $\left.N_{\alpha}-B o c-N_{\omega}-P b f-L-a r g i n i n e\right), ~ N-e t h y l-N^{\prime}-(3-$ dimethylaminopropyl)carbodiimide hydrochloride (EDAC), hydroxybenzotriazole $(\mathrm{HOBt}), \mathrm{N}, \mathrm{N}$-dimethylaminopyridine $(\mathrm{DMAP}), \mathrm{dry} \mathrm{CH}_{2} \mathrm{Cl} \mathrm{L}_{2}, \mathrm{rt}, \mathrm{for} \mathbf{2} \mathbf{a}$, or Boc-L-Lys(Boc)-OH, O-(benzotriazol-1-yl)- $\mathrm{N}, \mathrm{N}_{,} \mathrm{N}^{\prime}, \mathrm{N}^{\prime}$-tetramethyluronium hexafluorophosphate (HBTU), $\mathrm{N}, \mathrm{N}$-diisopropylethylamine (DIPEA), dry $\mathrm{CH}_{2} \mathrm{Cl} \mathrm{L}_{2}$, rt, for $\mathbf{2 b}$; (ii, 1) TFA/triisopropylsilane (TIS)/ $\mathrm{H}_{2} \mathrm{O}(95 / 2.5 / 2.5)$, rt, for $\mathbf{3 a}$, or TFA/triethylsilane $(\mathrm{TES}) / \mathrm{CH}_{2} \mathrm{Cl}_{2}(10 / 2.5 / 87.5)$ at $0{ }^{\circ} \mathrm{C}$ for $\mathbf{3 b}$, (2) dil. $\mathrm{HCl}$ in methanol, pH 4, rt; (iii) Cbz-L-Arg-OH, N, $\mathrm{N}^{\prime}$-dicyclohexylcarbodiimide (DCC), $\mathrm{HOBt}$, dry DMF, rt, $\mathrm{SAX}$ (strong anion exchange) sorbent (Cl-); (iv) $\mathrm{H}_{2}$ / $\mathrm{Pd}(\mathrm{C}), \mathrm{HCl}$, ethanol, rt. Boc: $t$-Butoxycarbonyl, Pbf: 2,2,4,6,7-pentamethyl-dihydrobenzofuran-5-sulfonyl, Cbz: carbobenzyloxy.
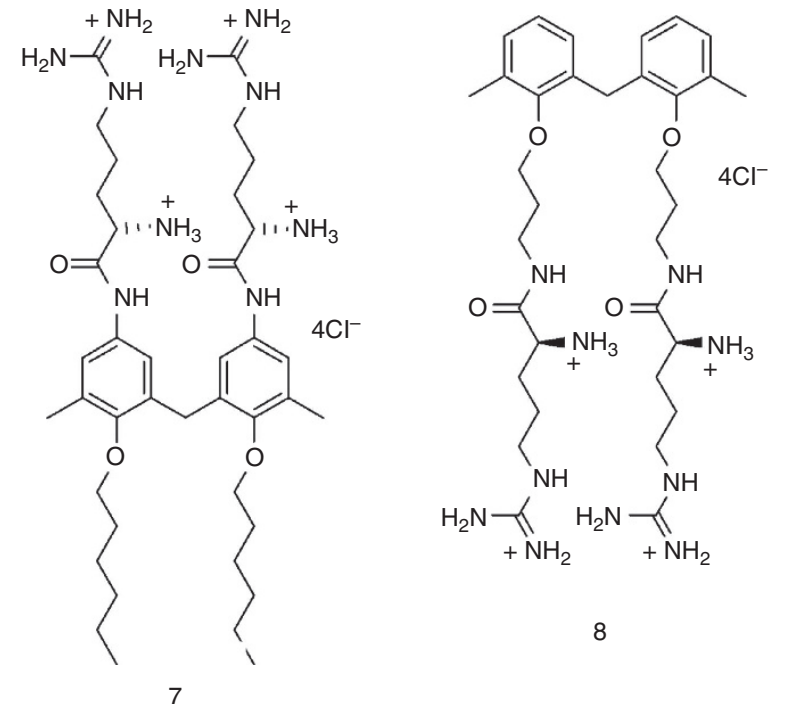

8

Figure 3 | Acyclic ligands. Gemini-type analogues of argininocalixarenes 3a and $\mathbf{6}$. For synthetic details relative to compounds $\mathbf{7}$ and $\mathbf{8}$, and their precursors see Supplementary Information.

shift assays (Supplementary Fig. S5) evidenced the ability of all calixarene (3a,b and 6) and Gemini-like (7 and 8) conjugates to interact with plasmid EGFP-C1 (4731 bp) expressing for green fluorescent protein. AFM experiments in tapping mode on air allowed to visualize the different effects of each of them on the DNA folding (Fig. 4 and Supplementary Fig. S6). The upper rim argininocalixarene $\mathbf{3 a}$ induces the DNA condensation to $50-60 \mathrm{~nm}$ globular species formed by a single $d s$-filament (Fig. 4a), and with proper dimension and compaction for cellular uptake. The lower rim arginino derivative 6 causes, on the contrary, the formation of large aggregates involving several filaments (Fig. 4b), partially reduced in size and in compaction degree by a decrease of the ligand concentration (Supplementary Fig. S6a). These multiplasmid aggregates are presumably too large to cross the cell membrane. Large aggregates are also formed by incubation of the plasmid with the lysino derivative $\mathbf{3 b}$ (Supplementary Fig. S6b), but the presence of DOPE, at a concentration double the calixarene, promotes the formation of small condensates (Fig. 4c) comparable in size with those obtained with $\mathbf{3 a}$ used alone. The treatment of DNA with the two non-macrocyclic compounds 7 and $\mathbf{8}$, up to $10 \mu \mathrm{M}$ concentration, does not generate globular condensates even if the interaction ability of the two ligands with the plasmids is unequivocally proved in AFM experiments by the DNA folding (Supplementary Fig. S6c,d), clearly different from the relaxed condition of the $d s$-filaments (Fig. $4 \mathrm{~d}$ ).

Transfection properties. To verify the ability of these compounds as gene-delivery systems, we selected for transfection the human Rhabdomyosarcoma (RD-4) cells because of their medical relevance and difficulty to be transfected by already established protocols and available formulations. A substantial agreement was found between the effect produced by the different ligands on the plasmid, observed by AFM (Fig. 4 and Supplementary 

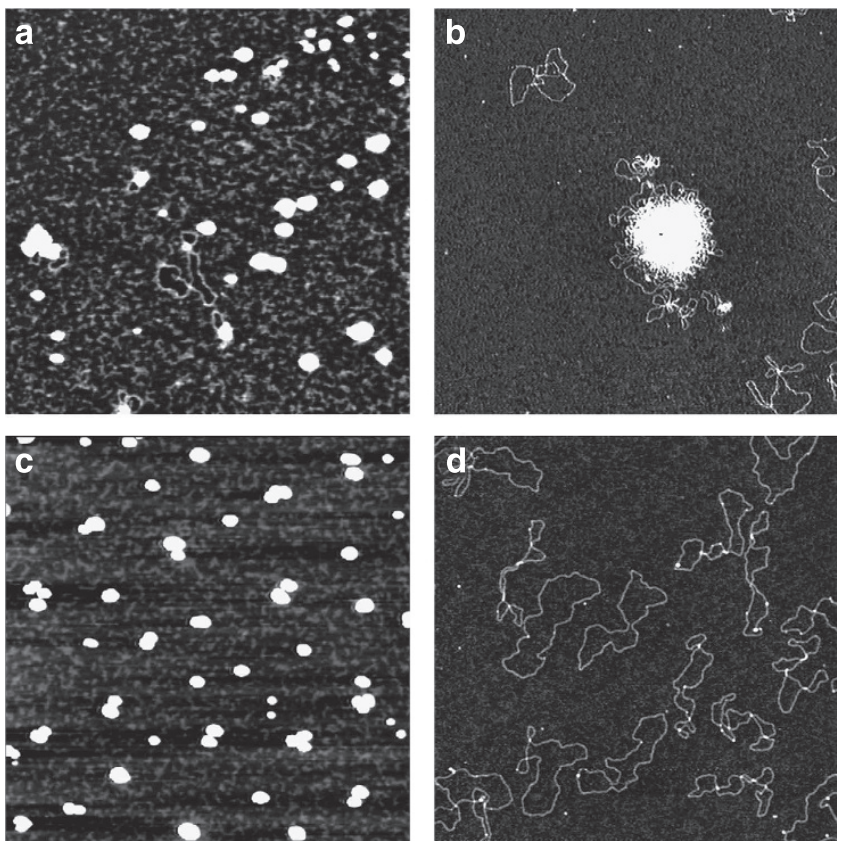

Figure 4 | AFM images of plasmid DNA. AFM images in tapping mode on air showing the effects induced on pEGFP-C1 plasmid DNA folding by incubation with (a) $2 \mu \mathrm{M}$ argininocalixarene $\mathbf{3 a}$; (b) $1 \mu \mathrm{M}$ argininocalixarene 6; (c) $2 \mu \mathrm{M}$ lysinocalixarene $\mathbf{3 b}$ in presence of DOPE (1,2-dioleoyl-snglycero-3-phosphoethanolamine) $4 \mu \mathrm{M}$; and (d) image of pEGFP-C1 plasmid DNA $0.5 \mathrm{nM}$ alone. Each image represents a $2 \times 2 \mu \mathrm{m}$ scan.

Fig. S6), and their ability and efficiency in the transfection process (Fig. 5 and Supplementary Fig. S7). The argininocalixarene 6 resulted a very poor vector and only in the presence of the adjuvant DOPE was able to deliver pEGFP-C1 DNA ( $1 \mathrm{nM})$ in 5\% of cells (Fig. 5 and Supplementary Fig. S7). The failure of $\mathbf{6}$ as a gene-delivery system can be ascribed to the absence of a significant lipophilic region able to counterbalance the polarity of the substituents at the lower rim. Moreover, the shape of this ligand and the volume occupied by the polar heads with respect to the lipophilic portion constituted only by the aromatic cavity is apparently not suitable to induce aggregation phenomena able to support a transfection activity. Its Gemini-type analogue $\mathbf{8}$ failed in transfection also in the presence of the helper. On the contrary, the activity shown by the upper rim argininocalix[4]arene $\mathbf{3 a}$ is impressive. At $10 \mu \mathrm{M}$ (cationic/anionic charges ratio $N / P=8.4$ ), it was able to transfect $75 \%$ of cells (Fig. 5a,b). Quite relevant is the comparison with its Gemini-type analogue 7 ( $9 \%$ of transfection but with DOPE) and with the commercially available LTX lipofectamine (35\%) and polyethyleneimine (PEI; $41 \%$ ) used as references (Fig. 5b). It is noteworthy the substantial inactivity observed for the lysine containing cluster $\mathbf{3 b}$, whose efficiency is indeed boosted by DOPE to percentages of transfected cells (41\%) only slightly lower than those obtained with the argininocalixarene 3a in presence of the adjuvant (46\%). Particularly striking is that the highest transfection efficiency is reached by $\mathbf{3 a}$ without the helper lipid DOPE, which otherwise is usually exploited to enhance the vector efficiency and minimize its toxicity. This underlines the per se potency of this vector and, in the specific context of transfection, would allow, in perspective, the use of this macrocyclic cationic surfactant without helpers, thus simplifying the formulations. Remarkably, in the presence of serum the delivery properties of $\mathbf{3 a}$ are only slightly reduced with a transfection efficiency over $60 \%$.
The same results were substantially confirmed by experiments with luciferase (Supplementary Fig. S8) again showing the higher efficiency of 3a with respect to the other ligands and LTX. The marked difference between the activity of $\mathbf{3 a}$ and that of its non-macrocyclic analogue 7 strengthens the hypothesis of a macrocyclic effect on the transfection process ${ }^{21}$. The rather low cytotoxicity of $\mathbf{3 a}$ (Supplementary Fig. S9), which, quite unusually, increases in the presence of DOPE, is also worth noting. In particular, in transfection conditions the level of cell viability in the presence of this argininocalixarene (Supplementary Fig. S9b) is very close to that observed with LTX.

The comparison between the structurally similar arginino cluster $\mathbf{3 a}$ and lysino-cluster $\mathbf{3 b}$ was widened by testing their transfection efficiency to other cell lines (Fig. 5c). Besides the C2C12 line to which both ligands resulted inactive and the LTX and PEI also have a very poor efficiency, in all other cases the superiority of the argininocalixarene $3 \mathbf{a}$ over the lysino analogue 3b, in absence of DOPE, appeared unequivocal (Fig. 5c). In fact for $3 \mathbf{b}$, at the best $18 \%$ of transfected cells was observed in the case of Hela, while for 3a more than $80 \%$ of transfection was obtained in the treatment of this cell line, more than $70 \%$ with N2a, 60\% with equine adipose-derived stromal cells (EADSCs), and more than $50 \%$ with Cos-7 and $40 \%$ with Vero cells. Moreover, excluding the cases of HEK cells, where LTX showed a significantly larger efficiency ( $75 \%$ versus ca. $50 \%$ ), and of the above mentioned $\mathrm{C} 2 \mathrm{C} 12$ cells, argininocalixarene 3a always resulted in a higher or at least comparable transfection activity with those of the references LTX and PEI. With EADSCs cell line, for instance, PEI was completely inefficient, whereas the $60 \%$ of transfection was obtained upon treatment with $\mathbf{3 a}$ that also almost doubled the LTX (36\%).

As in the experiments with RD-4 cells, the presence of DOPE, in general, decreased the transfection efficiency of $\mathbf{3 a}$, drastically in some cases (COS-7, HEK, ISHIKAWA lines), even if a small activity with $\mathrm{C} 2 \mathrm{C} 12$ cells was determined, which were not transfected at all in absence of adjuvant. On the other hand, the presence of DOPE transformed lysinocalixarene $\mathbf{3 b}$ in a vector (Fig. 5c), which was able to efficiently surpass the arginine cluster 3a in the case of HEK, ISHIKAWA, N2a and Vero cells, resulting in a better transfection efficiency for the latter two cell lines than all the other formulations.

This further supports the idea that simple clustering on the cone calix[4]arene scaffold of a single unit of basic amino acid for lipophilic tail can effectively represent a novel winning strategy to build potent cell-penetrating systems.

\section{Discussion}

In conclusion, the clustering of only four units of basic amino acids, such as arginine and lysine, on a rigid macrocyclic scaffold like cone calix[4]arene, displaying two spatially well-defined regions, one apolar at the lower rim and one polar at the upper rim, gives rise to new, potent non-viral vectors for cell transfection. In particular, in the case of the tetraargininocalix [4] arene $3 \mathbf{a}$, the one to one ratio between amino acid units and lipophilic tails is enough to reach this result, indicating that the circular array provided in this ensemble remarkably boosts the cell penetrating properties that arginine usually shows in linear oligomeric sequences and arginine-rich peptides, such as TAT HIV-1 fragments. The clearly higher efficiency of the arginino cluster 3a compared with analogue $\mathbf{3 b}$ bearing four lysine units, in absence of any adjuvant, underlines the superiority of arginine ${ }^{30}$ and then of guanidinium group in conferring to the vector its cell penetrating properties. Moreover, the high transfection efficiency shown by the tetralysinocalix[4]arene $\mathbf{3 b}$ when used with DOPE confirms the efficacy of this clustering strategy. The novel amino acid 
a

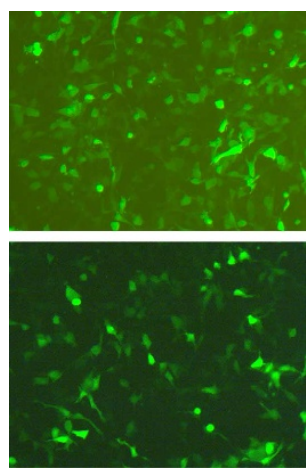

b 100

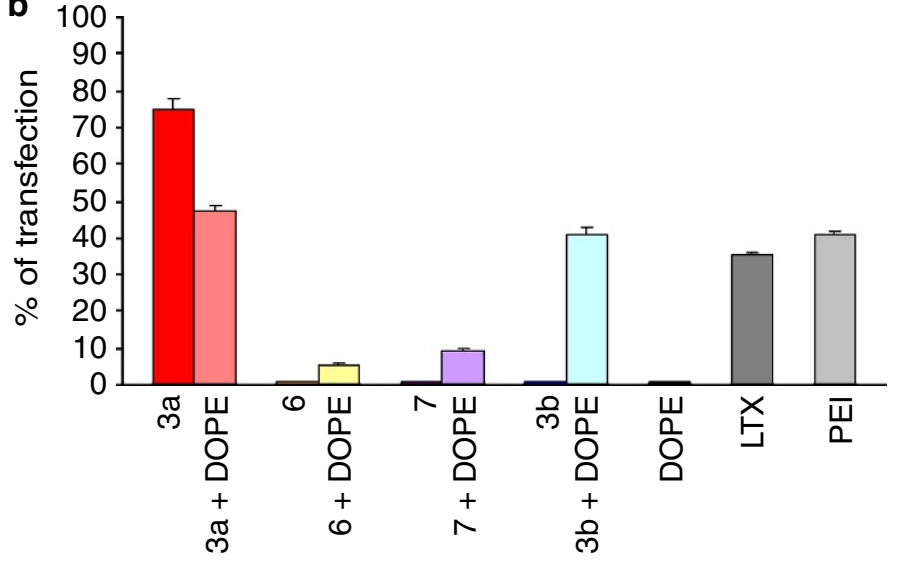

C

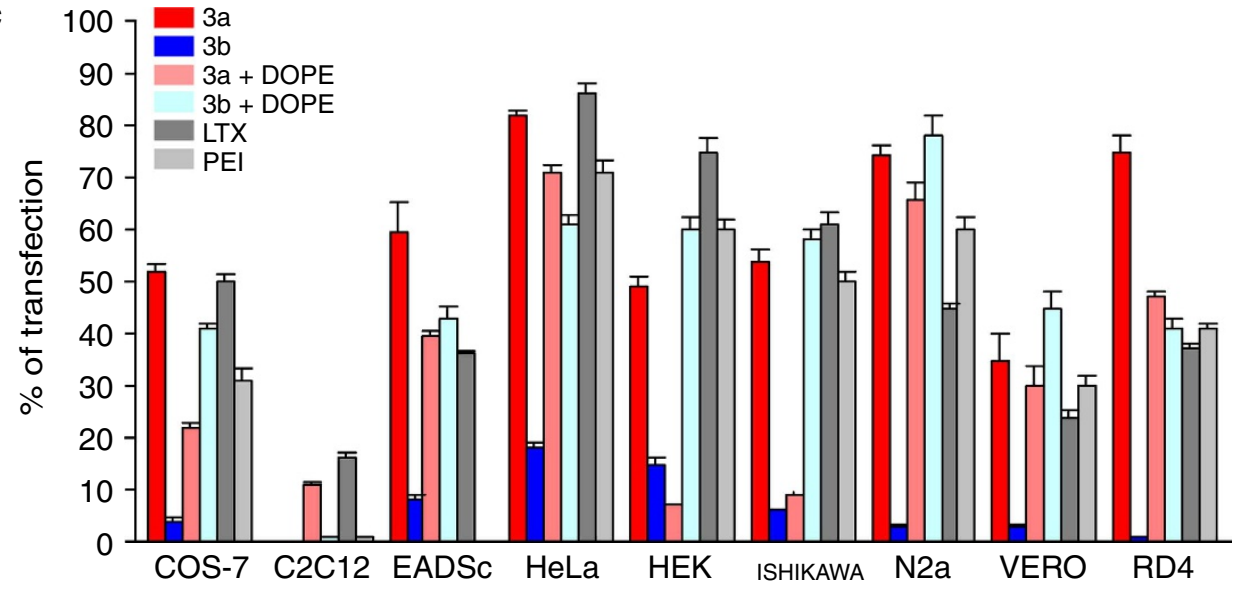

Figure 5 | Cell transfection experiments. (a) Images by fluorescence microscopy of human Rhabdomyosarcoma cells transfected (in green) upon treatment (at $48 \mathrm{~h}$ ) with EGFP-C1 plasmid $1 \mathrm{nM}$ formulated with (top) $10 \mu \mathrm{M}$ calixarene $\mathbf{3 a}$ and (bottom) LTX. In histogram $\mathbf{b}$, transfection efficiency (at $48 \mathrm{~h}$ ) to Rhabdomyosarcoma cells of argininocalix[4]arenes $\mathbf{3 a}$ and $\mathbf{6}$ compared with the non-macrocyclic model $\mathbf{7}$ (20 $\mu \mathrm{M}$ ), the lysinocalixarene $\mathbf{3 b}$, DOPE (1,2-dioleoyl-sn-glycero-3-phosphoethanolamine), LTX and PEI (polyethyleneimine). Error bars denote s.d. $(n>3)$. In histogram c, transfection efficiency to other cell lines of argininocalixarene $\mathbf{3 a}$ (red bar) compared with argininocalixarene $\mathbf{3 a}$ with DOPE (pale red bar), lysinocalixarene $\mathbf{3 b}$ (blue bar), lysinocalixarene $\mathbf{3 b}$ with DOPE (light blue bar), LTX (grey bar) and PEI (light grey bar). Calixarene derivatives and DOPE were used at 10 and $20 \mu \mathrm{M}$, respectively. Error bars denote s.d. $(n>3)$.

arrangement present in the peptidocalix[4]arenes $\mathbf{3} \mathbf{a}$ and $\mathbf{3 b}$ also makes additional primary amino groups available, which might favour the protection of the vector-DNA complex from the lysosomal degradation and facilitate the release of DNA from the endosomes inside the cytosol, through the proton sponge effect ${ }^{31-34}$, and thus increasing the transfection efficiency of the vectors. All these features make argininocalix[4]arene $\mathbf{3}$ a the progenitor of a new class of synthetic cationic surfactants, which could constitute a valuable alternative to commercially available formulations in transfection protocols, and suggest an unprecedented approach for the presentation of arginines in designing novel efficient cell-penetrating agents.

\section{Methods}

General. Moisture-sensitive reactions were carried out under a nitrogen atmosphere. Dry solvents were prepared according to standard procedures and stored over molecular sieves. Melting points were determined on an Electrothermal apparatus in capillaries sealed under nitrogen. ${ }^{1} \mathrm{H}$ and ${ }^{13} \mathrm{C}$ NMR spectra were recorded on Bruker AC300, AV300 and AV400 spectrometers (partially deuterated solvents were used as internal standards). For ${ }^{1} \mathrm{H}$ NMR spectra recorded in $\mathrm{D}_{2} \mathrm{O}$ at values higher than the room temperature, the correction of chemical shifts was performed using the equation $\delta=5.060-0.0122 \times \mathrm{T}\left({ }^{\circ} \mathrm{C}\right)+\left(2.11 \times 10^{-5}\right) \times$ $\mathrm{T} 2\left({ }^{\circ} \mathrm{C}\right)$, to determine the resonance frequency of water protons ${ }^{35}$. Electrospray ionization-mass spectrometry (ESI-MS) spectra were recorded on a single quadrupole instrument SQ Detector, Waters (capillary voltage $3.0-3.8 \mathrm{kV}$, cone voltage $30-160 \mathrm{eV}$, extractor voltage $3 \mathrm{eV}$, source block temperature $80^{\circ} \mathrm{C}$, desolvation temperature $150{ }^{\circ} \mathrm{C}$, cone and desolvation gas $\left(\mathrm{N}_{2}\right)$ flow rates 1.6 and $81 \mathrm{~min}^{-1}$, respectively). High-resolution mass spectrometry (HRMS) spectra were recorded on a LTQ Orbitrap XL instrument in ESI mode. Thin-layer chromatography was performed on Merck $60 \mathrm{~F}_{254}$ silica gel and Merck silica gel 60 RP-18. Flash column chromatography was performed on 230-400 mesh Merck 60 silica gel. HPLC purifications were performed on a 1100 Series Liquid Chromatograph Agilent, using an LC Detector. Strong anion-exchange $\left(\mathrm{Cl}^{-}\right)$cartridges were used.

5,11,17,23-Tetrakis(L-Arg-amino)-25,26,27,28-tetrakis(n-hexyloxy)calix[4] arene octa-hydrochloride (3a). A solution of calix[4]arene $\mathbf{2 a}(80 \mathrm{mg}, 2.8 \times$ $\left.10^{-2} \mathrm{mmol}\right)$ in trifluoroacetic acid (TFA)/triisopropylsilane $/ \mathrm{H}_{2} \mathrm{O}(95 / 2.5 / 2.5,5 \mathrm{ml})$ was stirred at room temperature. The progression of the reaction was followed by ESI-MS. After completion, the volatiles were removed under reduced pressure, the solid residue repeatedly suspended in ethyl acetate $(3 \times 5 \mathrm{ml})$, and the organic solvent evaporated to help in removing the exceeding TFA. The crude material was then washed with distilled diethyl ether $(3 \times 7 \mathrm{ml})$ and removed after sample centrifugation. The trifluoroacetate anion of the resulting TFA octa-salt was exchanged with chloride by dissolving the solid in a methanol solution of concentrated $\mathrm{HCl}(\mathrm{pH}=3-4)$ followed by evaporation $(4 \times)$. Compound 3 was obtained as white solid (37 mg, $\left.2.1 \times 10^{-2} \mathrm{mmol}, 75 \%\right)$; melting point $(\mathrm{mp}): 230^{\circ} \mathrm{C}$ dec; ${ }^{1} \mathrm{H}$ NMR $\left(300 \mathrm{MHz}, \mathrm{CD}_{3} \mathrm{OD}\right): \delta 7.18(\mathrm{~s}, 4 \mathrm{H}), 6.87(\mathrm{~s}, 4 \mathrm{H}), 4.47(\mathrm{~d}, J=12.9 \mathrm{~Hz}$ $4 \mathrm{H}), 4.06$ (bs, $4 \mathrm{H}), 3.90(\mathrm{t}, J=7.3 \mathrm{~Hz}, 8 \mathrm{H}), 3.40-3.20(\mathrm{~m}, 8 \mathrm{H}), 3.16$ $(\mathrm{d}, J=12.9 \mathrm{~Hz}, 4 \mathrm{H}), 1.98(\mathrm{bs}, 16 \mathrm{H}), 1.72(\mathrm{bs}, 8 \mathrm{H}), 1.50-1.20(\mathrm{~m}, 24 \mathrm{H}), 0.94$ $(\mathrm{t}, J=6.3 \mathrm{~Hz}, 12 \mathrm{H}) ;{ }^{13} \mathrm{C}$ NMR $\left(75 \mathrm{MHz}, \mathrm{CD}_{3} \mathrm{OD}\right): \delta 167.9,158.9,155.1,136.6$, $136.5,133.2,122.6,122.1,77,54.8,42.2,33.7,32.4,31.8,30.2,27.6,25.9,24.3,14.8$ (see Supplementary Fig. S10); MS $(\mathrm{m} / z):[\mathrm{M}+2 \mathrm{H}-8 \mathrm{HCl}]^{2+}$ calcd. for 
$\mathrm{C}_{76} \mathrm{H}_{132} \mathrm{Cl}_{8} \mathrm{~N}_{20} \mathrm{O}_{8}, 723.5$; found, 723.7; HRMS $(\mathrm{m} / z)$ : $[\mathrm{M}+2 \mathrm{H}-8 \mathrm{HCl}]^{2+}$ calcd. for $\mathrm{C}_{76} \mathrm{H}_{132} \mathrm{Cl}_{8} \mathrm{~N}_{20} \mathrm{O}_{8}, 723.5028$; found, 723.5027 .

\section{Synthesis of 5,11,17,23-Tetrakis(L-Lys-amino)-25,26,27,28-tetrakis( $n$-hex-} yloxy)calix[4]arene octahydrochloride (3b). A solution of calix[4]arene $\mathbf{2 b}$ (11.5 mg, $5.4 \times 10^{-3} \mathrm{mmol}$ ) in $\mathrm{CH}_{2} \mathrm{Cl}_{2} / \mathrm{TFA} /$ triethylsilane $(87.5 / 10 / 2.5,1 \mathrm{ml})$ was stirred at $0{ }^{\circ} \mathrm{C}$. The progression of the reaction was followed using MS. After completion, the volatiles were removed under reduced pressure. The crude material was suspended in diethyl ether $(5 \mathrm{ml})$, centrifuged and the organic solvent removed $(3 \times)$. The TFA anion of the resulting TFA octa-salt was exchanged with chloride by dissolving the solid in a methanol solution of concentrated $\mathrm{HCl}(\mathrm{pH}=3-4)$ followed by evaporation $(3 \times)$. Compound $\mathbf{3 b}$ was obtained as white solid (8.5 mg, quantitative); mp: $215^{\circ} \mathrm{C} \mathrm{dec} ;{ }^{1} \mathrm{H} \mathrm{NMR}\left(300 \mathrm{MHz}, \mathrm{CD}_{3} \mathrm{OD}\right): \delta 7.21$ $(\mathrm{d}, J=2.4 \mathrm{~Hz}, 4 \mathrm{H}), 6.85(\mathrm{~d}, J=2.4 \mathrm{~Hz}, 4 \mathrm{H}), 4.47(\mathrm{~d}, J=12.9 \mathrm{~Hz}, 4 \mathrm{H}), 4.03$ $(\mathrm{t}, J=6.6 \mathrm{~Hz}, 4 \mathrm{H}), 3.92(\mathrm{t}, J=7.5 \mathrm{~Hz}, 8 \mathrm{H}), 3.15(\mathrm{~d}, J=12.9 \mathrm{~Hz}, 4 \mathrm{H}), 2.97$ $(\mathrm{t}, J=7.5 \mathrm{~Hz}, 8 \mathrm{H}), 2.08-1.83(\mathrm{~m}, 16 \mathrm{H}), 1.82-1.65(\mathrm{~m}, 8 \mathrm{H}), 1.63-1.25(\mathrm{~m}, 32 \mathrm{H})$, $0.95(\mathrm{t}, 12 \mathrm{H}, J=6.7 \mathrm{~Hz}) ;{ }^{1} \mathrm{H}$ NMR $\left(300 \mathrm{MHz}, \mathrm{D}_{2} \mathrm{O}, c=1 \mathrm{mM}\right): \delta 7.30(\mathrm{~d}, J=2.4$ $\mathrm{Hz}, 4 \mathrm{H}), 6.85(\mathrm{~d}, J=2.4 \mathrm{~Hz}, 4 \mathrm{H}), 4.47(\mathrm{~d}, J=13.0 \mathrm{~Hz}, 4 \mathrm{H}), 4.12-3.95$ $(\mathrm{m}, 12 \mathrm{H}), 3.35(\mathrm{~d}, J=13 \mathrm{~Hz}, 4 \mathrm{H}), 3.02(\mathrm{t}, J=7.8 \mathrm{~Hz}, 8 \mathrm{H}), 2.12-1.86(\mathrm{~m}, 16 \mathrm{H})$ $1.82-1.62(\mathrm{~m}, 8 \mathrm{H}), 1.61-1.23(\mathrm{~m}, 32 \mathrm{H}), 0.94(\mathrm{t}, J=6.9 \mathrm{~Hz}, 12 \mathrm{H}) ;{ }^{13} \mathrm{C}$ NMR $\left(150 \mathrm{MHz}, \mathrm{CD}_{3} \mathrm{OD}\right): \delta 167.9,154.8,136.3,133,122.3,121.8,76.8,54.7,40.4,33.4$, $32.2,32.1,31.5,28.2,27.3,24.1,23.1,14.6$ (see Supplementary Fig. S11); MS ( $/ \mathrm{m} / \mathrm{z}$ ): $[\mathrm{M}+2 \mathrm{H}-8 \mathrm{HCl}]^{2+}$ calcd. for $\mathrm{C}_{76} \mathrm{H}_{132} \mathrm{Cl}_{8} \mathrm{~N}_{12} \mathrm{O}_{8}$, 667.5; found, 667.6; HRMS $(\mathrm{m} / \mathrm{z})$ : $[\mathrm{M}+3 \mathrm{H}-8 \mathrm{HCl}]^{3+}$ calcd. for $\mathrm{C}_{76} \mathrm{H}_{132} \mathrm{Cl}_{8} \mathrm{~N}_{12} \mathrm{O}_{8}, 445.3294$; found, 445.3293 .

\section{5,26,27,28-Tetrakis[3-(L-Arg-amino)propoxy]calix [4]arene octa-hydro-} chloride (6). Calix[4]arene $\mathbf{5}\left(80 \mathrm{mg}, 4.1 \times 10^{-2} \mathrm{mmol}\right)$ was dissolved in $\mathrm{MeOH}$ $(13 \mathrm{ml})$ and a catalytic amount of $\mathrm{Pd} / \mathrm{C}(10 \%)$ was added. Hydrogenation for the Cbz group removal was carried out at $2 \mathrm{~atm}$ in a Parr reactor for $24 \mathrm{~h}$. Progression of the reaction was followed by ${ }^{1} \mathrm{H}$ NMR and ESI-MS. The reaction was quenched by catalyst filtration and the solvent removed under reduced pressure. Crude was dissolved in $10 \mathrm{ml}$ water, filtered on a nylon $0.45-\mu \mathrm{m}$ filter and purified by HPLC (column: Jupiter $4 \mu \mathrm{m}$ Proteo $90 \mathrm{~A}, \mathrm{C}-12,90 \mathrm{~A}, 10 \times 250 \mathrm{~mm}$, elution conditions: eluent $\mathrm{A}, \mathrm{H}_{2} \mathrm{O}+0.1 \%$ formic acid; eluent $\mathrm{B}, \mathrm{MeOH}+0.1 \%$ formic acid; $100 \%$ A over $5 \mathrm{~min}, 100 \%$ A to $84 / 16 \mathrm{~A} / \mathrm{B}$ over $5 \mathrm{~min}, 84 / 16$ to $74 / 26$ $\mathrm{A} / \mathrm{B}$ over $20 \mathrm{~min}$, at $4 \mathrm{ml} \mathrm{min}^{-1}$ ). The fractions containing the pure product were collected and evaporated under reduced pressure. The formiate anion of the resulting salt was exchanged by adding $\mathrm{HCl} 37 \%$ to a methanol solution $(5 \mathrm{ml})$ of the solid residue till $\mathrm{pH} 3$, followed by evaporation under reduced pressure $(4 \times)$ and liophilization, to give 6 as white powder $\left(41 \mathrm{mg}, 2.7 \times 10^{-2} \mathrm{mmol}, 65 \%\right)$; mp: $182-185^{\circ} \mathrm{C} ;{ }^{1} \mathrm{H}$ NMR $\left(400 \mathrm{MHz}, \mathrm{CD}_{3} \mathrm{OD}\right): \delta 8.70(\mathrm{bt}, 4 \mathrm{H}), 6.63(\mathrm{~d}, J=6.6 \mathrm{~Hz}$, $8 \mathrm{H}), 6.57(\mathrm{t}, J=6.6 \mathrm{~Hz}, 4 \mathrm{H}), 4.44(\mathrm{~d}, J=13.4 \mathrm{~Hz}, 4 \mathrm{H}), 4.08(\mathrm{t}, J=6.4 \mathrm{~Hz}, 4 \mathrm{H})$, $4.02(\mathrm{t}, J=6.4 \mathrm{~Hz}, 8 \mathrm{H}), 3.52(\mathrm{t}, J=6.8 \mathrm{~Hz}, 8 \mathrm{H}), 3.30(\mathrm{t}, J=5.1 \mathrm{~Hz}, 8 \mathrm{H}), 3.21$ (d, $J=13.4 \mathrm{~Hz}, 4 \mathrm{H}), 2.33-2.12(\mathrm{~m}, 8 \mathrm{H}), 2.06-1.85(\mathrm{~m}, 8 \mathrm{H}), 1.81-1.63(\mathrm{~m}, 8 \mathrm{H})$; ${ }^{1} \mathrm{H}$ NMR $\left(300 \mathrm{MHz}, \mathrm{D}_{2} \mathrm{O}, c=2.4 \mathrm{mM}\right): \delta 6.84(\mathrm{~d}, J=7.4 \mathrm{~Hz}, 8 \mathrm{H}), 6.72$ $(\mathrm{t}, J=7.4 \mathrm{~Hz}, 4 \mathrm{H}), 4.41(\mathrm{~d}, J=13.2 \mathrm{~Hz}, 4 \mathrm{H}), 4.14-3.90(\mathrm{~m}, 12 \mathrm{H}), 3.72-3.55$ $(\mathrm{m}, 4 \mathrm{H}), 3.46-3.30(\mathrm{~m}, 4 \mathrm{H}), 3.35(\mathrm{~d}, J=13.2 \mathrm{~Hz}, 4 \mathrm{H}), 3.19(\mathrm{t}, J=6.9 \mathrm{~Hz}, 8 \mathrm{H})$, $2.36-2.10(\mathrm{~m}, 8 \mathrm{H}), 1.96-1.80(\mathrm{~m}, 8 \mathrm{H}), 1.70-1.52(\mathrm{~m}, 8 \mathrm{H}) ;{ }^{13} \mathrm{C} \mathrm{NMR}(100 \mathrm{MHz}$, $\left.\mathrm{CD}_{3} \mathrm{OD}\right): \delta 170.1,158.6,157.5,136.1,129.5,123.4,73.9,54.1,41.9,38.4,32,31.2$, 29.9, 25.6 (see Supplementary Fig. S12); MS $(\mathrm{m} / \mathrm{z})$ : $[\mathrm{M}+2 \mathrm{H}-8 \mathrm{HCl}]^{2+}$ calcd. for $\mathrm{C}_{64} \mathrm{H}_{108} \mathrm{Cl}_{8} \mathrm{~N}_{20} \mathrm{O}_{8}, 639.4$; found, 639.9; HRMS $(\mathrm{m} / \mathrm{z}):[\mathrm{M}+2 \mathrm{H}-8 \mathrm{HCl}]^{2+}$ calcd. for $\mathrm{C}_{64} \mathrm{H}_{108} \mathrm{Cl}_{8} \mathrm{~N}_{20} \mathrm{O}_{8}, 639.4089$; found, 639.4087 .

The synthesis, characterization, spectroscopic information for all other compounds reported in the article and ${ }^{1} \mathrm{H}$ and ${ }^{13} \mathrm{C}$ NMR spectra (Supplementary Figs S13 and S14) can be found in the Supplementary Methods.

\section{Cell culture and transient transfection assay. RD-4 (human Rhabdomyo-} sarcoma cell line (obtained from David Derse, National Cancer Institute, Frederick, MD)), C2C12 (mouse myoblast; ATCC (\#CRL-1772)), N2a (mouse neuroblastoma; ATCC (\#CCL-131)), EADSCs primary culture was obtained as described in Donofrio et al. ${ }^{36}$ ), COS-7 (African green monkey kidney cells; ATCC (\#CRL1651)), VERO (African green monkey kidney cells; ATCC (\#CCL-81)), HEK 293 (human embryo kidney cells; ATCC (\#CRL-1573)), ISHIKAWA (human endometrial cancer cells; ECACC (\#99040201)) and HeLa (human cervix adenocarcinoma; ATCC (\#CCL-2)) were grown in EMEM medium containing NEAA, $10 \%$ fetal bovine serum, $2 \mathrm{mM}$ L-glutamine, $100 \mathrm{IU} \mathrm{ml}^{-1}$ penicillin and $100 \mu \mathrm{g} \mathrm{ml}^{-1}$ streptomycin. All cultures were incubated at $37^{\circ} \mathrm{C}$ in a humidified atmosphere containing $5 \% \mathrm{CO}_{2}$. Cells were subcultured to a fresh culture vessel when growth reached $70-90 \%$ confluence (that is, every 3-5 days) and incubated at $37^{\circ} \mathrm{C}$ in a humidified atmosphere of $95 \%$ air and $5 \% \mathrm{CO}_{2}$. Transfections were performed in 24 -well plates, when cells were $80 \%$ confluent $\left(\sim 5 \times 10^{4}\right.$ cells $)$ on the day of transfection. Plasmid $(2.5 \mu \mathrm{g})$ and different concentrations of ligands were added to $1 \mathrm{ml}$ of serum-free medium (DMEM, $2 \mathrm{mM} \mathrm{L}$-glutamine and $50 \mu \mathrm{g} \mathrm{ml}^{-1}$ ), mixed rapidly and incubated at room temperature for $20 \mathrm{~min}$. When used, serum was added at this point to the transfection solution. Following the removal of the culture medium from the cells, $0.5 \mathrm{ml}$ of transfection mixture were carefully added to every well. Lipoplex formulations with helper lipid were prepared adding a $2 \mathrm{mM}$ ethanol solution of DOPE to plasmid-ligand mixture at 1/2 ligand/DOPE molar ratio, where ligand concentration was kept to $10 \mu \mathrm{M}$. These solutions administered to the cells were completely clear and homogeneus. LTX transfection reagent was used according to manufacturer's protocol as a positive transfection control. The mixture and cells were incubated at $37^{\circ} \mathrm{C}$ in a humidified atmosphere of $95 \%$ air and $5 \% \mathrm{CO}_{2}$ for $5 \mathrm{~h}$. Finally, transfection mixture was removed and $1 \mathrm{ml}$ of growth medium added to each transfected well and left to incubate for $72 \mathrm{~h}$. Five fields were randomly selected from each well without viewing the cells (one in the centre and one for each quadrant of the well) and examined. The transfected cells were observed under fluorescence microscope for enhanced green fluorescent protein expression. Each experiment was done at least three times. Statistical differences between treatments were calculated with student's $t$-test and multifactorial analysis of variance.

\section{References}

1. Futaki, S. et al. Arginine-rich peptides. An abundant source of membranepermeable peptides having potential as carriers for intracellular protein delivery. J. Biol. Chem. 276, 5836-5840 (2001).

2. Nakase, I., Takeuchi, T., Tanaka, G. \& Futaki, S. Methodological and cellular aspects that govern the internalization mechanisms of arginine-rich cellpenetrating peptides. Adv. Drug Deliv. Rev. 60, 598-607 (2008).

3. Walrant, A., Bechara, C., Alves, I. D. \& Sagan, S. Molecular partners for interaction and cell internalization of cell-penetrating peptides: how identical are they? Nanomedicine 7, 133-143 (2012).

4. Vivès, E., Brodin, P. \& Lebleu, B. A truncated HIV-1 Tat protein basic domain rapidly translocates through the plasma membrane and accumulates in the cell nucleus. J. Biol. Chem. 272, 16010-16017 (1997).

5. Torchilin, V. P., Rammohan, R., Weissig, V. \& Levchenko, T. S. Tat peptide on the surface of liposomes affords their efficient intracellular delivery even at low temperature and in the presence of metabolic inhibitors. Proc. Natl Acad. Sci. USA 98, 8786-8791 (2001).

6. El-Sayed, A., Khalil, I. A., Kogure, K., Futaki, S. \& Harashima, H. Octaarginineand octalysine-modified nanoparticles have different modes of endosomal escape. J. Biol. Chem. 283, 23450-23461 (2008).

7. Rothbard, J. B. et al. Conjugation of arginine oligomers to cyclosporin a facilitates topical delivery and inhibition of inflammation. Nat. Med. 6, 1253-1257 (2000).

8. Said Hassane, F., Saleh, A. F., Abes, R., Gait, M. J. \& Lebleu, B. Cell penetrating peptides: overview and applications to the delivery of oligonucleotides. Cell. Mol. Life Sci. 67, 715-726 (2010).

9. Maitani, Y. \& Hattori, Y. Oligoarginine-PEG-lipid particles for gene delivery. Exp. Opin. Drug Deliv. 6, 1065-1077 (2009).

10. Nakase, I. et al. Efficient intracellular delivery of nucleic acid pharmaceuticals using cell-penetrating peptides. Acc. Chem. Res. 45, 1132-1139 (2012).

11. Hoyer, J. \& Neundorf, I. Peptide vectors for the nonviral delivery of nucleic acids. Acc. Chem. Res. 45, 1048-1056 (2012).

12. Mann, A. et al. Differences in DNA condensation and release by lysine and arginine homopeptides govern their DNA delivery efficiencies. Mol. Pharmaceutics 8, 1729-1741 (2011).

13. Crombez, L., Morris, M. C., Heitz, F. \& Divita, G. A non-covalent peptidebased strategy for ex vivo and in vivo oligonucleotide delivery. Methods Mol. Biol. 764, 59-73 (2011).

14. Crombez, L. \& Divita, G. A non-covalent peptide-based strategy for siRNA delivery. Methods Mol. Biol. 683, 349-360 (2011).

15. Futaki, S. et al. Stearylated arginine-rich peptides: a new class of transfection systems. Bioconjug. Chem. 12, 1005-1011 (2001).

16. Lehto, T. et al. Delivery of nucleic acids with a stearylated (RxR)4 peptide using a non-covalent co-incubation strategy. J. Contr. Rel. 141, 42-51 (2010).

17. Lättig-Tünnemann, G. et al. Backbone rigidity and static presentation of guanidinium groups increases cellular uptake of arginine-rich cell-penetrating peptides. Nat. Commun. 453, 1-6 (2011).

18. Ortiz Mellet, C., García Fernández, J. M. \& Benito, J. M. Cyclodextrin-based gene delivery systems. Chem. Soc. Rev. 40, 1586-1608 (2011).

19. Sansone, F. et al. DNA condensation and cell transfection properties of guanidinium calixarenes: dependence on macrocycle lipophilicity, size, and conformation. J. Am. Chem. Soc. 28, 14528-14536 (2006).

20. Lalor, R., Di Gesso, J. L., Mueller, A. \& Matthews, S. E. Efficient gene transfection with functionalised multicalixarenes. Chem. Commun. 4907-4909 (2007).

21. Bagnacani, V. et al. Macrocyclic non-viral vectors: high cell transfection efficiency and low toxicity in a lower rim guanidinium calix[4]arene. Org. Lett. 10, 3953-3956 (2008).

22. Bagnacani, V. et al. Lower rim guanidinocalix[4]arenes: macrocyclic nonviral vectors for cell transfection. Bioconjug. Chem. 23, 993-1002 (2012).

23. Rodik, R. V. et al. Virus-sized dna nanoparticles for gene delivery based on micelles of cationic calixarenes. Chem. Eur. J. 17, 5526-5538 (2011).

24. Peters, M. S., Li, M. \& Schrader, T. Interactions of calix[n]arenes with nucleic acids. Nat. Prod. Commun. 7, 409-417 (2012).

25. Hu, W. B. et al. Dimeric calixarenes: a new family of major-groove binders. Chem. Eur. J. 18, 3589-3597 (2012).

26. Pietersz, G. A., Choon-Kit, T. \& Apostolopoulos, V. Structure and design of polycationic carriers for gene delivery. Mini Rev. Med. Chem. 6, 1285-1298 (2006). 
27. Casnati, A., Sansone, F. \& Ungaro, R. Peptido- and glycocalixarenes: playing with hydrogen bonds around hydrophobic cavities. Acc. Chem. Rev. 36, 246-254 (2003).

28. Baldini, L., Casnati, A., Sansone, F. \& Ungaro, R. Calixarene-based multivalent ligands. Chem. Soc. Rev. 36, 254-266 (2007)

29. Casnati, A. et al. Calixarene based picolinamide extractants for the selective An/ Ln separation from radioactive waste. Eur. J. Org. Chem. 2338-2348 (2005).

30. Mann, A. et al. Differences in DNA condensation and release by lysine and arginine homopeptides govern their DNA delivery efficiencies. Mol. Pharm. 8, 1729-1741 (2011).

31. Behr, J. P., Demeneix, B., Loeffler, J. P. \& Perez-Mutul, J. Efficient gene transfer into mammalian primary endocrine cells with lipopolyamine-coated DNA. Proc. Natl Acad. Sci. USA 86, 6982-6986 (1989).

32. Boussif, O. et al. A versatile vector for gene and oligonucleotide transfer into cells in culture and in vivo: polyethylenimine. Proc. Natl Acad. Sci. USA 92, 7297-7301 (1995)

33. Akinc, A., Thomas, M., Klibanov, A. M. \& Langer, R. J. Exploring polyethylenimine-mediated DNA transfection and the proton sponge hypothesis. J. Gene Med. 7, 657-663 (2005).

34. Behr, J. P. Synthetic gene transfer vectors II: back to the future. Acc. Chem. Res. 45, 980-984 (2012).

35. Gottlieb, H. E., Kotlyar, V. \& Nudelman, A. NMR chemical shifts of common laboratory solvents as trace impurities. J. Org. Chem. 62, 7512-7515 (1997).

36. Donofrio, G. et al. Virally and physically transgenized equine adipose-derived stromal cells as a cargo for paracrine secreted factors. Cell Biol. 11, 73 (2010).

\section{Acknowledgements}

We acknowledge the Ministero dell'Istruzione, Università e Ricerca (MIUR, PRIN-project MultiNanoIta number 2010JMAZML), COST projects CM1005 'Supramolecular
Chemistry in water' and CM1102 'MultiGlycoNano', and Fondazione Cassa di Risparmio di Parma for the financial support, and the Centro Interdipartimentale Misure 'G. Casnati' for the use of NMR and AFM facilities, and for high-resolution mass spectrometry.

\section{Author contributions}

V.B., M.B. and M.L. carried out synthesis, characterization of experiments and binding studies. V.F. carried out electrophoretic mobility shift assay (EMSA), cytotoxicity and transfection studies. G.D. carried out EMSA, cytotoxicity and transfection studies and helped in planning the experiments. F.S. carried out AFM studies, helped in planning experiments and in designing the project, and participated in the preparation of the manuscript. A.C. and R.U. helped in planning experiments and in designing the project and participated in the preparation of the manuscript.

\section{Additional information}

Supplementary Information accompanies this paper at http://www.nature.com/ naturecommunications

Competing financial interests: The authors declare no competing financial interests.

Reprints and permission information is available online at http://npg.nature.com/ reprintsandpermissions/

How to cite this article: Bagnacani, V. et al. Arginine clustering on calix[4]arene macrocycles for improved cell penetration and DNA delivery. Nat. Commun. 4:1721 doi: $10.1038 /$ ncomms2721 (2013).

(c) (1) $\odot$ This work is licensed under a Creative Commons AttributionNonCommercial-NoDerivs 3.0 Unported License. To view a copy of this license, visit http://creativecommons.org/licenses/by-nc-nd/3.0/ 